\title{
CAMbRII)GE
}

\section{The Plasma Universe}

\section{Curt Suplee}

\begin{abstract}
"A lively, compact, beautifully illustrated and eminently readable exposition of the amazing scope of modern plasma physics. The common phenomena underlying plasma TV's sunspots and the violent death of stars are lucidly explained at level suitable for a broad audience. I particularly liked the onepage profiles of the scientists who shaped the subject, starting with Irving Langmuir, that are sprinkled throughout the text: they provide welcome historical context and human interest."

- Curtis Callen, Professor of Physics, Princeton University, and President-Elect, American Physical Society
\end{abstract}

"In The Plasma Universe Curt Suplee explains in an entertaining way and in educated layman's terms what constitutes plasmas, their complex behavior, the history of plasma science right up to the use of plasmas in modern day and future technologies. In these pages is a concise summary of our current understanding of strange and beautiful phenomena on earth and in stars and galaxies around us. I recommend (this book) for anyone who likes to look at beautiful pictures and who might be interested in the history of science and the process of discovery and innovation."

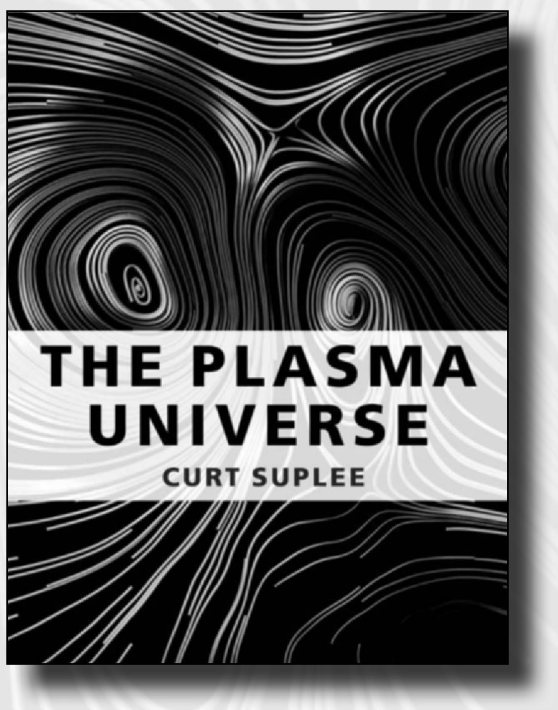

\$20.99: Pb: 978-0-521-51927-4: 88 pp.

-Cherry Murray, Dean, Harvard School of Engineering and Applied Sciences, and President, American Physical Society

$\mathrm{P}$ lasma physics is the fascinating science behind lightning bolts, fluorescent lights, solar flares, ultra-bright TV screens, fusion reactors, cosmic jets and black hole radiation, to name but a few examples. Yet plasmas obey their own, often very surprising, rules and repeatedly defy our best efforts to anticipate and control them. This richly illustrated book reveals, for the first time, the exciting world of plasma physics to a non-technical audience. It describes the phenomena and follows the worldwide research effort to comprehend them, taking the reader on a journey from neighborhood neon lights to the remotest galaxies and beyond. The lively text is interspersed with fascinating photographs and explanatory diagrams, giving readers a deeper understanding of the world around them. 


\section{CAMBRIDGE JOURNALS}

\section{journals.cambridge.org Advancing research. Increasing access.}

Informed by detailed consultation with the library and research communities, we are constantly developing our industry-leading online journals platform.

Some recent advances include:

- Refreshed site design, facilitating rapid access to the most relevant content.

- New advanced search interface and a more detailed, fielded quick search function.

- Enriched content in the form of multimedia companions and editorial blogs.

- Launch of Cambridge Open Option, our open access initiative.

Visit journals.cambridge.org/openoption for more information. 


\section{CAMBRIDGE}

\section{JOURNALS}

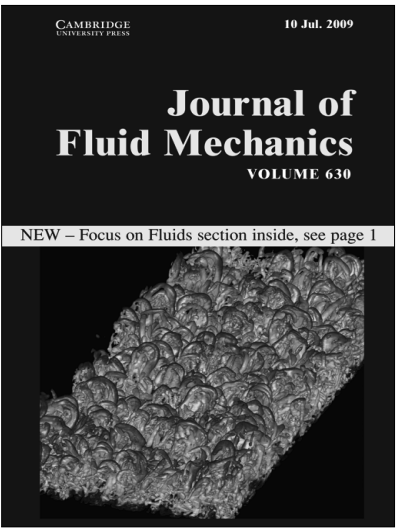

Journal of Fluid Mechanics

is available online at

http://journals.cambridge.org/flm

To subscribe contact

Customer Services

in Cambridge:

Phone +44 (0)1223 326070

Fax +44 (0)1223 325150

Email journals@cambridge.org

\section{in New York:}

Phone +1 (845) 3537500

Fax +1 (845) 3534141

Email

subscriptions_newyork@cambridge.org

\section{Journal of Fluid Mechanics}

Editors

S. H. Davis, Northwestern University , USA

M. G. Worster, University of Cambridge, UK

Journal of Fluid Mechanics publishes authoritative articles covering theoretical, computational and experimental investigations of all aspects of the mechanics of fluids. Papers discuss both the fundamental aspects of fluid mechanics, and their applications to other fields such as aeronautics, astrophysics, physiology, chemical and mechanical engineering, oceanography, geology, and combustion.

Price information is available at http://journals.cambridge.org/flm

\section{Free email alerts}

Keep up-to-date with new material - sign up at http://journals.cambridge.org/alerts 


\section{CAMBRIDGE}

\section{JOURNALS}

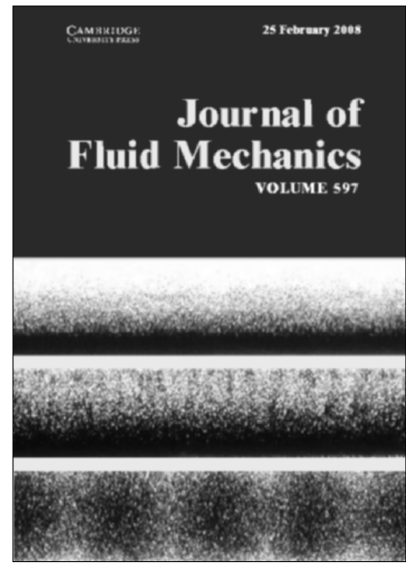

Journal of Fluid Mechanics Digital Archive

is available online at

journals.cambridge.org/jfm

To subscribe contact Customer Services

in Cambridge:

Phone +44 (0)1223 326070

Fax +44 (0)1223 325150

Email journals@cambridge.org

in New York:

Phone (845) 3537500

Fax (845) 3534141

Email

subscriptions_newyork@cambridge.org
Journal of Fluid Mechanics Digital Archive

\section{Current Editor}

Stephen H. Davis, Northwestern University , USA

The Journal of Fluid Mechanics Digital Archive is a repository of every single article published in the Journal of Fluid Mechanics between 1956 and 1996. It houses around 200,000 pages of material, reproduced as high-resolution PDFs, and is fully searchable. The Archive marks the complete digitisation of the Journal of Fluid Mechanics, with all material from 1997 onwards available through Cambridge Journals Online.

Price information is available at journals.cambridge.org/jfm

\section{Free email alerts}

Keep up-to-date with new material sign up at journals.cambridge.org/register 


\section{CAMBRIDGE}

\section{JOURNALS}

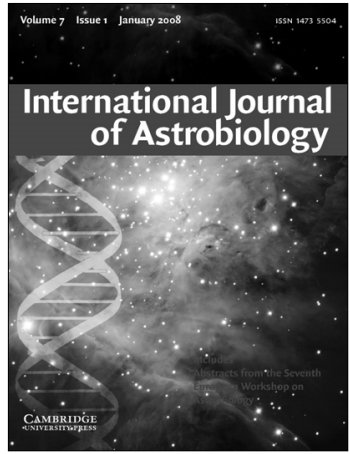

International Journal of

\section{Astrobiology}

is available online at:

http://journals.cambridge.org/ija

To subscribe contact

Customer Services

in Cambridge:

Phone $+44(0) 1223326070$

Fax $+44(0) 1223325150$

Email journals@cambridge.org

in New York:

Phone +1(845) 3537500

Fax +1 (845) 3534141

Email

subscriptions_newyork@cambridge.org

\section{International Journal of Astrobiology}

\section{Managing Editor \\ Simon Mitton, University of Cambridge , UK}

Astrobiology combines the sciences of biology, chemistry, palaeontology, geology, atmospheric physics, planetary science, astrophysics and cosmology in the study of the origin, evolution and distribution of life in the universe. The International Journal of Astrobiology acts as an important forum for practitioners in this rapidly expanding field.

\section{Price information is available at: http://journals.cambridge.org/ija}

\section{Free email alerts}

Keep up-to-date with new material - sign up at http://journals.cambridge.org/alerts 


\section{Advertising Opportunities}

To advertise in this journal and for details of pricing, availability and discount opportunities please contact:

\section{Advertising in UK, Europe and rest of world}

The Advertising Sales Team

Cambridge University Press

The Edinburgh Building,

Shaftesbury Road,

Cambridge, UK, CB2 8RU

Tel: +44 (0)1223 325083

Email: ad_sales@cambridge.org

\section{Advertising in USA, Mexico and Canada}

Journals Advertising Coordinator

32 Avenue of the Americas,

New York,

NY 10013-2473, USA

Tel: +1 (212) 3375053 Fax: +1 (212 337 5959)

E-mail: journals_advertising@cambridge.org

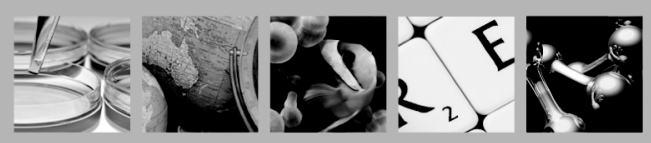




\section{Instructions for Authors}

Editorial policy The journal welcomes submissions in any of the areas of plasma physics. Its scope includes experimental and theoretical work on basic plasma physics, the plasma physics of magnetic and inertial fusion, laser-plasma interactions, industrial plasmas, plasma devices and plasmas in space and astrophysics. This list is, of course, merely illustrative of the wide range of topics on which papers are invited, and is not intended to exclude any aspect of plasma physics that is not explicitly mentioned.

Authors are urged to ensure that their papers are written clearly and attractively, in order that their work will be readily accessible to readers. Manuscripts must be written in English. Journal of Plasma Physics employs a rigorous peer-review process whereby all submitted manuscripts are sent to recognized experts in their subjects for evaluation. The Editors' decision on the suitability of a manuscript for publication is final.

Submission of manuscripts Papers may be submitted to the Editor or any of the Associate Editors, preferably by email in pdf format. When a paper is accepted, the authors will be asked to supply source files in LaTeX or Word. Instructions for the preparation of these files and LaTeX style files are given in the Instructions for Contributors link at journals.cambridge.org/pla.

Incremental publishing and DOIs In order to make articles which have been accepted for publication in Journal of Plasma Physics available as quickly as possible, they are now published incrementally online (at Cambridge Journals Online; journals.cambridge.org) The online version is available as soon as author corrections have been completed and before the article appears in a printed issue. A reference is added to the first page of the article in the journal catchline. This is the DOI - Digital Object Identifier. This is a global publishers' standard. A unique DOI number is created for each published item. It can be used for citation purposes instead of volume, issue and page numbers. It therefore suits the early citation of articles which are published on the web before they have appeared in a printed issue. See journals.cambridge.org/pla.

Proof reading Only typographical or factual errors may be changed at proof stage. The publisher reserves the right to charge authors for correction of non-typographical errors.

Offprints 50 offprints of each article will be supplied free to each first-named author. Extra offprints may be purchased from the publisher if ordered at proof stage. No page charge is made.

Copying This journal is registered with the Copyright Clearance Center, 222 Rosewood Drive, Danvers, MA 01923. Organizations in the USA who are also registered with C.C.C. may therefore copy material (beyond the limits permitted by sections 107 and 108 of US copyright law) subject to payment to C.C.C. of the per copy fee of $\$ 16.00$. This consent does not extend to multiple copying for promotional or commercial purposes. Code 0022-3778/2009 \$16.00.

ISI Tear Sheet Service, 3501 Market Street, Philadelphia, Pennsylvania 19104, USA, is authorized to supply single copies of separate articles for private use only.

Organizations authorized by the Copyright Licensing Agency may also copy material subject to the usual conditions.

For all other use, permission should be sought from Cambridge or the American Branch of Cambridge University Press. 


\title{
JOURNAL OF PLASMA PHYSICS
}

\author{
Volume 75 Part 5 October 2009
}

\section{CONTENTS}

\section{Letters to the Editor}

Dark and grey electromagnetic electron-cyclotron envelope solitons in an electron-positron magnetoplasma

P. K. SHUKLA, R. BINGHAM, A. D. R. PHELPS and L. STENFLO

Low-frequency electrostatic wave in a metallic electron-hole-ion plasma with nanoparticles

P. K. SHUKLA and G. E. MORFILL

\section{Articles}

A note on the trapped electron dust grain current

ABDERREZAK BERBRI and MOULOUD TRIBECHE

Stability of ion-acoustic solitary waves in a multi-species magnetized plasma consisting of non-thermal and isothermal electrons

SK. ANARUL ISLAM, A. BANDYOPADHYAY and K. P. DAS

Experimental and computational characterization of hydrodynamic expansion of a preformed plasma from thin-foil target for laser-driven proton acceleration AKITO SAGISAKA, HIDEO NAGATOMO, HIROYUKI DAIDO, ALEXANDER S. PIROZHKOV, KOICHI OGURA, SATOSHI ORIMO, MICHIAKI MORI, MAMIKO NISHIUCHI, AKIFUMI YOGO and MASATAKA KADO

Particle acceleration in a reconnecting current sheet: PIC simulation

TARAS V. SIVERSKY and VALENTINA V. ZHARKOVA

Magnetohydrodynamic stability of plasmas with ideal and relaxed regions

R. L. MILLS, M. J. HOLE and R. L. DEWAR

Characteristics of the runaway electron beam instability in the HT-7 tokamak

Z. Y. CHEN, J. X. ZHU, H. J. JU, Q. DU, Y. J. SHI, H. F. LIANG, M. LI,

W. D. CAI and HT-7 TEAM

Resonant interaction of runaway electrons with magnetic field ripple

in tokamak plasmas

Z. Y. CHEN, B. N. WAN, Y. J. SHI, H. J. JU, J. X. ZHU and H. F. LIANG

Guiding-center recursive Vlasov and Lie-transform methods in plasma physics

A. J. BRIZARD and A. MISHCHENKO

Dust-acoustic nonlinear periodic waves in a dusty plasma with charge fluctuation

L. L. YADAV, S. V. SINGH and R. BHARUTHRAM 